\title{
This is thy brother's voice - Documentary and metadocumentary linguistic work with a folklore recording from the Nenets-Komi contact area ${ }^{\star}$
}

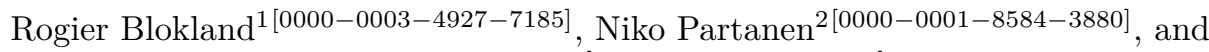 \\ Michael Rießler 3 [0000-0002-2397-2860] \\ 1 Uppsala University \\ rogier.blokland@moderna.uu.se \\ 2 University of Helsinki \\ niko.partanen@helsinki.fi \\ 3 University of Eastern Finland \\ michael.riessler@uef.fi
}

\begin{abstract}
In this paper we analyse an epic song, performed by Ulita Koskova in 1966 in Kolva in the Komi ASSR, and recorded by the Hungarian-Australian researcher Erik Vászolyi, and discuss its background and wider historical context. We look at different ways how such material can contribute to data-driven and sociolinguistically oriented research, specifically in connection to contemporary documentary linguistics, and point to directions for further research.
\end{abstract}

Keywords: Contact Linguistics - Corpus Linguistics · Ethnomusicology · Dialectology · Documentary Linguistics · Finite State Morphology · History of Research · Linguistic Anthropology · Sociolinguistics - Tundra Nenets · Zyrian Komi

\section{Introduction}

This is thy brother's voice...

(Ulita Koskova, in Komi; 13755_2az.230 25:11-25:15)

In this paper we examine the recording of a song in Komi, commonly described as an epic song and known as the 'Ballad of the soft-haired sister' (Komi Небыд юрсиа чой помлась, Russian Сестра с мягкими волосами). ${ }^{1}$ The song and a

\footnotetext{
* Corresponding author is Niko Partanen. Many thanks to Karina Lukin (Helsinki) who gave us a deeper insight into Nenets folklore, to Katalin Lázár (Budapest) who furnished details on the whereabouts of Erik Vászolyi's recordings in Hungary, and to Joshua Wilbur (Tartu) for his valuable comments. The introductory quotes in the title and in the beginnings of each section are from the original English translation of the recording by Erik Vászolyi. Our work was embedded in a larger project supported by a grant from Kone Foundation.

${ }^{1}$ Other alternative names are also sometimes found, e.g. Komi Небыд юрсия ныв помлась, Russian Девушка мягкие волосы.
} 
retelling of its content in prose were recorded in the village of Kolva in the north of the Komi ASSR in 1966. Although this may at first glance seem like a very narrow topic, we show that as a case study it can lead to wide-ranging reflections on evolving language documentation practices during the last hundred years, in addition to including anthropologically and sociolinguistically interesting data.

Last but not least, our work with this legacy recording and concomitant metadata is closely connected to previous work by Jack Rueter, honoured with the present Festschrift, who has contributed significantly to the computational modelling of Komi morphology.

Our small-scale study illustrates the complexities of research activities aiming at collecting, annotating, studying and publishing this kind of data. Specifically, it is an example of how legacy materials can be integrated into contemporary multimedia corpora, following best practice developed in documentary linguistics. While carrying out an analysis of a few exemplary linguistic features, we want to show how such limited material can lead to gainful observations on structural linguistic and sociolinguistic phenomena.

Archived corpus material of this type exists in considerable quantities and for a variety of under-researched languages, but typically this is analysed manually. We therefore also look at this legacy recording from a corpus linguisticperspective and discuss challenges and opportunities for computational processing, specifically taking into account the existing morphosyntactic analyser based on Finite State Morphology (Rueter 2000).

When discussing individual recording segments we refer to them with the identifier used in the Tape Archive of the Finnish Language, separated with a full stop from the numbering in our own transcriptions, and with the time stamp that matches the recordings digitized in Finland. We cannot guarantee the time stamp exactly matches the other versions (which we discuss in the next section), but they should help in locating the relevant sections in those as well.

\section{History of the recording}

They set out on a trek...

(Ulita Koskova, in Komi; 13755_2az.009 08:50-08:55)

The recording was made on the 22nd of October 1966 in the village of Kolva near Usinsk in the north of what was then the Komi ASSR; the performer was Ulita Alekseevna Koskova, born in 1896 (fl. 1972) (Vászolyi-Vasse and Lázár 2010, p. 52). ${ }^{2}$ The exact composition of the research group that recorded the song is unknown, but some sleuthing allows us to state with near certainty that it only included the Komi linguist Gennadij Grigor'evič Baraksanov (19341997) and the Hungarian linguist Erik Vászolyi (1933-2013; a.k.a. Erik VászolyiVasse, Eric Vasse). Vászolyi's participation in the original fieldwork was not mentioned in the Russian publication by Mikušev (1969a, p. 3), perhaps because

\footnotetext{
${ }^{2}$ More biographical info about Ulita Koskova can be found in Vászolyi 1967a, pp. 438439 and Vászolyi-Vasse 1999, p. XL.
} 
Vászolyi was a foreigner. In a later publication (Mikušev 1991, p. 358), the participation of Vászolyi and also of Károly Rédei in expeditions in the 1960s to the Komi ASSR is acknowledged; Vászolyi and Rédei, however, were never there at the same time. Rakin $(2017$, p. 80 ), on the other hand, writes that Vászolyi collected the text in Kolva, without mentioning Baraksanov, implying that it was Vászolyi alone; Vászolyi himself, however, always uses the plural, referring to Baraksanov as the other collector present, and in his 1967 article he specifically thanks Baraksanov (and nobody else) as the other participant on the trip, whilst the Komi folklorists Jurij Ročev and Vladimir Timin are thanked for their help with deciphering unclear parts in the recorded material, which in all probability took place only after Vászolyi and Baraksanov had returned to Syktyvkar at the beginning of November 1966 (cf. notes in Vászolyi 1967a, p. 441; Vászolyi-Vasse 1999, p. XXIV; Vászolyi-Vasse 2001, p. XXI; Vászolyi-Vasse and Lázár 2010, p. 24).

As far as we have been able to ascertain, at least the following six versions of the song have been published. A retelling of the content of the song in prose form (henceforth called 'prose version') by Ulita Koskova, recorded the following day, has been published at least five times.

- Transcription and Hungarian translations of both the song and the prose version (Vászolyi 1968)

- Transcription and Russian translation of the song (Mikušev 1969a, pp. 218229)

- Transcription and English translations of both the song and the prose version (Vászolyi-Vasse 2001, pp. 66-99)

- Transcription, musical notation and Hungarian translations of both the song and the prose version (Vaszolyi and Lázár 2008, pp. 51-69)

- Transcription, musical notation and English translations of both the song and the prose version (Vászolyi-Vasse and Lázár 2010, pp. 52-71)

- Transcription, musical notation and Russian translations of both the song and the prose version (Vasoj and Lazar 2010) ${ }^{3}$

Another prose version of the same content, also narrated by Ulita Koskova, was recorded by Fedor Vasil'evich Plesovskij and Nadežda Dimitrievna Bomberger in 1972 in Kolva (Panjukov 2015, p. 110), but this seems to not have been published anywhere; the material that Plesovskij and Bomberger collected is archived in Syktyvkar at the Komi Scientific Centre of the Ural Branch of the Russian Academy of Sciences. ${ }^{4}$ There is also yet another prose version of the song published in Mikušev's collection of Komi epic songs in Russian (Mikušev 1991, pp. 335-341); interestingly this is slightly different than the one in Mikušev 1969a.

\footnotetext{
${ }^{3}$ The 2010 English and Russian versions are translations of the 2008 Hungarian version.

${ }^{4}$ Плесовский Ф. В., Бомбергер Н. Д. Материалы Печорской фольклорной экспедиции за 1972 г. // НА Коми НЦ. Ф. 5. Оп. 2. Д. 89. 386 л.
} 
It also seems that all published versions in the different languages use the same line division system, where the song text contains 233-236 metrical lines or verses (in some versions originally repeated lines are only shown once).

The only musical transcription of the song, which can be found in the 2008 Hungarian version (Vaszolyi and Lázár 2008) (and therefore also in the 2010 English and Russian versions of the book, i.e. Vászolyi-Vasse and Lázár 2010 and Vasoj and Lazar 2010), was provided by Katalin Lázár from Budapest. ${ }^{5}$

With regard to technical equipment used for the recording not much is known: we know that Vászolyi had an Agfa tape recorder with him on his first trip to the Komi Republic in 1959-60, and probably also on the second trip in 1966, when the present recording was made (Vászolyi-Vasse and Lázár 2010, pp. 18, 21). We do not know the exact model, and whether the recorder was the same on both trips (Vászolyi does refer to his "much-travelled tape recorder" Vászolyi-Vasse and Lázár 2010, p. 21 in 1966, so it is likely it was the same one).

On his second trip to the USSR in 1966, however, Vászolyi was subject to more restrictions by the Soviet authorities and could not travel as freely as before. He was only allowed to go to the Komi ASSR after spending more than three months in Moscow (Vászolyi-Vasse and Lázár 2010, p. 20), and he also mentions that during this trip "it was seen as a special favour that I was permitted to carry my own tape recorder" (Vászolyi-Vasse and Lázár 2010, p. 25).

He also took photographs (Vászolyi-Vasse and Lázár 2010, p. 22) with his own camera (Vászolyi 1967b, p. 435). There are two pictures taken by Vászolyi during his 1966 trip in his 1967 article, regrettably not in Kolva, though he does mention taking photographs there (Vászolyi 1967b, p. 439), and there are 28 photographs in the 2008 Hungarian version (Vaszolyi and Lázár 2008, pp. 375390), but not in the English one; none of these were taken in Kolva either.

With regard to his audio recording equipment, which at the time was dependent on power outlets and not on batteries, it is also interesting to mention Vászolyi's problems with electricity:

A worse problem was, in most villages, that the power supply was restricted to a few hours after sunset with regular blackouts (hence the quality of our tape recordings sometimes suffered).

(Vászolyi-Vasse and Lázár 2010, p. 25)

In the beginning of the song's recording there is a section that lasts 2.23 seconds where the recording has not captured any audio signal besides background hiss. This could be related to the electricity problems, although the exact cause is not documented anywhere. Vászolyi-Vasse and Lázár (2010, p. 54) marked this with a footnote where this technical issue is mentioned. What makes this technical glitch worth commenting is that it is occurs in the sentence where the name of one of the main characters, the protagonist's sister, is mentioned. The segment could be read as 'soft-haired sister', and this is the term used for the sister in the prose version too, whereas in some published versions a personal name of Nenets

${ }^{5}$ Lázár has also provided musical transcriptions for other recordings made by Vászolyi; see Lázár (2007). 
origin is suggested (Vászolyi-Vasse and Lázár 2010, p. 54). To resolve questions like this we can only hope that additional recorded variants and versions stored in different archives can be studied at a later date.

This leads to the question of the location of the original tapes and various copies of the material that Vászolyi recorded. One copy was left in the possession of the Komi Research Institute in Syktyvkar (now the Komi Scientific Centre, which is part of the Ural Branch of the Russian Academy of Sciences) and another copy was later made in Helsinki and archived at the Tape Archive of the Finnish Language located at the Institute for the Languages of Finland. Vászolyi emigrated from Hungary to the United Kingdom in 1968, and two years later to Australia (Vászolyi-Vasse and Lázár 2010, p. 24). He took the original recordings with him to Australia (Vászolyi-Vasse 1999, p. XXIV) where, as far as we know, they remain, but Vászolyi had obviously also made a copy of his recordings which was deposited in Hungary at the Institute of Musicology. The current state of our knowledge is therefore that audio recordings of the song in question are at present available in at least three locations: in Syktyvkar at the Komi Scientific Centre (exact archival location unknown), in Budapest at the Institute of Musicology (now part of the Research Centre of the Humanities of the Hungarian Academy of Sciences), registered under CD 5004, with MG 6872A3 the name of Vászolyi's original tape recording, and in the Tape Archive of the Finnish Language, registered under signums 13755 and 13756. We are not aware of any photographs (such as the ones mentioned above) or field notes being archived with any of the mentioned institutions. There remains of course the possibility of data deposited with institutions or private individuals in Australia, about which we regrettably know nothing.

\section{The song and its ethno-linguistic context}

The Samoyeds have a custom...

(Ulita Koskova, in Komi; 13755_2az.162 20:19-20:23)

Among the subgroups of the Zyrian Komi the so-called Iźva Komi (or Izhva Komi; Komi изьватас; Russian ижемцы; Nenets ңысма"; henceforth 'Iźvatas', with 'Iźva' referring to the language variety) are perhaps the best known, being the only such group that have traditionally been reindeer herders, and the only group that can be found in substantial numbers outside of the Komi Republic (on the Kola Peninsula, in the Nenets Autonomous Okrug, the Yamalo-Nenets Autonomous Okrug, and the Khanty-Mansi Autonomous Okrug).

The Iźvatas are generally thought to have come into being through the admixture of Komi subgroups which made their way north from the 16th century onwards, mainly from the areas along the river Vym, up along the river Izhma. They then soon came into contact with Russians from the west, and finally with Nenets from the north, from the middle of the 18th century onwards (Žerebcov 1982, pp. 108-109); it is from the Nenets that the Iźvatas learned reindeer herding. Contacts with Russians of course continue till today, but contacts with 
speakers of Tundra Nenets are nowadays mainly limited to those Iźvatas who herd reindeer in the Nenets Autonomous Okrug, which is situated north of the Komi Republic, and in the Yamalo-Nenets Autonomous Okrug, which is situated to the north-east.

It is not known exactly when the Komi first came into contact with the Nenets; there are no extant accounts of this having happened any time before the middle of the 16th century. The exact ethnic affiliation of the people present in the Pechora basin before the 15th century is also not clear (Žerebcov 1982, pp. 157-158).

The Komi also had early contacts further eastwards, especially because they also used the well-known trade route connecting northern Europe with western Asia (Russian чрезкаменный путь 'the Trans-Ural route'), which, starting in Ustyug, followed the river system $(\mathrm{Vym}>$ Uhkta $>$ Izhma $>$ Pechora $>$ Usa $>$ Sob $>$ Ob'); using this route the Komi perhaps reached western Siberia already in the 12th century (Povod 2006, p. 31), though there is no early proof of any contact with the Nenets. More localized contacts between the Iźvatas and Nenets then occurred in the area of the present-day Komi Republic, and in 1679 contacts between Iźvatas and Nenets in the Izhemskaja sloboda are already documented in census records. Contacts also occurred north or northwest of the present-day Komi Republic, in the course of the movement of the Iźvatas into the Bol'shezemelskaja Tundra, whilst written sources also show that Nenets made their way to the Mezen', undoubtedly by crossing Komi territory, already in the 18th century (Lašuk 1958, pp. 104-105).

At the time the Nenets were mostly nomadic, but in the early 1800s a group of Nenets originally from the Bol'shezemelskaja Tundra abandoned their traditional reindeer herding lifestyle and settled permanently around the village of Kolva (about $15 \mathrm{~km}$ from present-day Usinsk) which had been founded in 1820; they were formally baptized in 1826 (Žerebcov 1982, p. 166), and a church was founded there in 1827 (Istomin 1999, p. 22). More Nenets settled there between the 1860 s and 1880 s, mainly due to their livelihoods being destroyed as a result of epizootic diseases and overgrazing drastically reducing their reindeer herds. There are a number of ethnonyms used for these Iźva-speaking Kolva Nenets: Komi колва яран 'the Kolva Nenets' (as opposed to тундра яран оr выненьчи 'the (Nenets-speaking) Nenets of the Malozemelskaja and Bol'shezemelskaja tundra)', колватас 'the Kolva', колва коми 'the Kolva Komi' (as opposed to изьватас 'the Iźva Komi'), колваса, колвасаяс 'the Kolva, Kolvas' (Mikušev 1973, p. 6). There is some disagreement in the literature as to how many people still consider themselves to belong to this ethnic group and whether they are to be found only in and around Usinsk or also north of the Komi Republic, in the Nenets Autonomous Okrug (Lašuk 1958, p. 188; Homič 1966, p. 22; Žerebcov 1982; Istomin 1999, p. 168; Habeck 2005, pp. 203-205). The shift from Tundra Nenets to Iźva occurred within a few generations: the Finnish Samoyedologist Toivo Lehtisalo mentions that in 1912 in Kolva he met only one older man who spoke Nenets, who, when he sang to others in Nenets, had to explain the song's content (Lehtisalo 1956, p. LXXIV), and Lashuk, writing in the 1950s, claims that 
"nearly nobody speaks Nenets anymore", though its not exactly clear to what time period he refers (Lašuk 1958, p. 182). Vászolyi, during his 1966 visit to Kolva, mentions that nobody could even count to 10 in Nenets, and that he and his linguist companion knew more Nenets words than the inhabitants of Kolva did.

To our knowledge no Nenets grammatical substrate features have been described for the Kolva subdialect of Iźva Komi, only individual lexical items. Lyktin cautiously wonders whether deaffrication (mentioned in more detail further below) in Iźva could be of Nenets origin (Lytkin 1949, p. 149). Vászolyi agrees with Lytkin (Vászolyi-Vasse 1999, p. 223), at least concerning the Iźva spoken on the Kanin Peninsula; further study is obviously needed. As mentioned above, linguistic shift was not accompanied by a total assimilation to (Iźvatas) Komi culture. The Kolva people retained many aspects of Nenets culture - reindeer herding mentioned above being one of them - and also remained aware of their Nenets origin. They self-identified as Nenets, and often also kept their Nenets surnames, and also retained the Nenets song tradition (Nenets ярабц and сюдбабц), and it is this last aspect that specifically interests us in the present paper. The Kolva epic song tradition has been considered 'Northern Komi' (eg. Mikušev 1973), Nenets (Homič 1966, pp. 147-149) or as mixed Komi-Nenets (Žerebcov 1982, p. 173); the singer of this song, Ulita Koskova, said it was a "Komi song in a Nenets voice" (Vászolyi 1967a, pp. 438-439). For a more detailed description of Kolva epic songs see Mikušev (1969b).

\section{Linguistic observations}

Then thou speak up and say this...

(Ulita Koskova, in Komi; 13755_2az.180 21:37-21:41)

The published transcriptions differ from one another mainly in minor details. They are generally very accurate ${ }^{6}$ and close examination does not reveal essential deviations from the song text recorded in the audio.

An important exception are numerous self-corrections, repetitions and hesitations, which are systematically ignored in the original transcripts of both the sung and prose versions of the recording. The only exception is single footnote in Vászolyi's transcription where a self-correction is indicated (Vászolyi-Vasse and Lázár 2010, p. 59). Vászolyi explicitly mentions having refrained from editing the texts and adhering to the actual utterances recorded on tape (VászolyiVasse 1999, p. XXXVII), but he seems to have referred only to grammatically or lexically inconsistent forms in the speech recording which he retained in the transcript and also often commented on in his text editions, rather than selfcorrections and related phenomena. In fact, the aforementioned footnote explains the informant's self-correction of a lexical item from line 155 in line 156 (13755_2az.155-156 19:46-19:56) We detected eight self-corrections of different

${ }^{6}$ Vászolyi points out that there were some 'annoying misprints' in the first version from 1968 (Vászolyi-Vasse 1999, p. XXIII) 
types in the sung version, and there are at least fifteen instances in the prose version. We have carefully reintroduced these features into our digital version of the transcripts because they are clearly a feature of the originally recorded data and might provide valuable cues for future linguistic studies. ${ }^{7}$ Some of them are connected to the content, e.g. that the number of participants is corrected, or the segment is restarted with a more specific word. All of these occur within a line, which probably also was the level at which they were ignored in earlier transcriptions.

In addition to self-corrections, there are a few other instances of slight differences between the various transcripts. Especially in the printed transcripts of the sung version it may not always be obvious which one provides the correct interpretation of the recorded speech. Some of these impressions or open interpretations coincide with dialectal features that are reported as typical for Iźva Komi, and for the Kolva subdialect as well, although showing extensive variation which is not yet fully accounted for in descriptive and sociolinguistic terms. Interestingly, our small data sample nicely illustrates several examples of such under-studied variation.

One of these features is l-vocalization, which we describe below in connection to epenthetic vowels. Another feature is deaffrication, which is a process where the palatal affricates $/ \mathrm{t}_{\varphi} /$ and $/ \mathbf{d}_{\odot} /$ are replaced with corresponding stops $/ \mathrm{c} /$ and $/ \mathfrak{f} /$. This process is typical for Iźva dialect, with some reported internal variation (Punegova and Popova 2019, p. 42). Typically this variation also regards incomplete deaffrication, i.e. where slight affrication is still perceivable, but much less prominent. In the recordings discussed here deaffrication occurs often in the voiced affricate $/ \mathbf{d}_{\mathrm{e}} /$ in all environments, but only very sporadically in the affricate/te/.

Another dialectal phenomenon undergoing variation and also commented on by Vászolyi is the lack of number agreement (i.e. footnote comment VászolyiVasse 2001, p. 483). In Example 1 the subject is a plural third person pronoun, but the verbform is in the singular instead of in the expected plural кучисныс.

\section{(1) ныа тай кучис мунны нин и.}

nia taj kut6-is munni nin (i)

3PL so start-3SG.PST go-INF already (i)

'They already started to go.' (13755_2az.009 08:50-08:55)

Vászolyi describes this phenomena as sporadic yet persistent in the Kolva Usa variety of Iźva Komi (Vászolyi-Vasse 2001, p. 11). This topic too deserves further analysis, but based on the authors' fieldwork experience with this dialect it does not appear to be a feature particularly common for Iźva Komi as a whole.

Another particularity of these texts is the regular use of dative objects. Klumpp (2009, p. 343) reports that with regard to these epic songs and their

\footnotetext{
${ }^{7}$ For a more detailed discussion of self-corrections and related phenomena in spoken language corpora, and specifically their usefulness in interactional linguistic research, see the study on Nganasan by Kaheinen (2020).
} 
corresponding prose versions dative objects are more common in the prose versions. This also obtains for our texts, which are a subset of the materials studied by Klumpp, and we can report one dative object from the song and four from the prose version. We see this in Example 2 from the prose version, where the object, 'boat', is marked with a dative.

(2) Ырген пыжлы суутэдіс, мыльк юр вылэ кайис.

irgen piz-li suited-is, miKk jur vil-e kaj-is.

copper boat-DAT stop-3SG.PST hill head on-ILL climb-3SG.PST

'He stopped the copper boat, climbed to top of the hill.'

(13756_2bz.115 28:42-28:45)

The dative object in dialectal Komi has been the topic of much research (Baker 1985, pp. 202-221), and Klumpp (2008, pp. 167-216) has exhaustively described occurrences of dative objects in varieties of Komi, including Iźva and its subdialects. As these dative forms are thus exceedingly rare in many text collections and recordings, but occur multiple times even in a small text such as the present one, it might nevertheless be a worthwhile enterprise for Komi dialectology to locate and describe the use of dative objects specifically in all the sub-varieties of Iźva Komi in (even) more detail.

These observations about Iźva Komi dialectal characteristics in this recording are not novel, and have been previously mentioned in the dialectological literature, but they show in an illustrative manner that the respective isoglosses are valid only to a varying degree even in such a remote Iźva Komi variety as Kolva Iźva Komi. This also raises the question of how useful they are as typical dialect features, and how much they represent a late areal feature that has spread in Komi dialects that are no longer in contact.

In addition to clearly phonological or grammatical features like in the examples above, there are also many instances of epenthetic vowels, which occur as the sounds [i] or [e]. Sound insertions (or deletions, for that matter) are generally typical in singing and are often used to fulfil metre requirements while following the language's phonotactic and prosodic rules. For instance in the Tundra Nenets singing tradition, such regular insertions have been described as added and transformed syllables (e.g. Niemi 2016, p. 27; Lukin 2017, p. 200).

There are several examples where epenthetic vowels undoubtedly have a metrical function, especially when they appear word-internally. This is true for the examples нярт(а)ласэ, ${ }^{8}$ чер(и)нас and куль(ы)ны. We see in Example 3 that in the word for 'axe' the vowel is inserted between the stem and a plural third person possessive suffix.

8 This example also marked in Vászolyi's transcription (Vászolyi-Vasse and Lázár 2010, p. 57). The same word occurs also without the vowel in these texts. 
(3) ме чер(и)нас лӧседча да нин

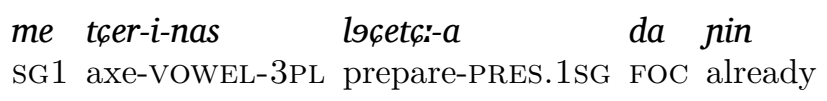

'I'm already preparing (to hit) with an axe.' (13755_2az.224 24:47-24:50)

The text includes also an example of the same word (in another inflected form) without any insertion, but there is no reason to analyse this as lexical variation between two stems (i.e. ме чер- ме чери-) because the word 'axe' has never been described anywhere in the literature as having this kind of variation and чериis an otherwise highly frequent lexeme in Komi (and Iźva Komi) meaning 'fish'. Note also that the duration of the inserted sound [i] is similar to the following $[a]$, i.e. the average duration of other (singleton) vowels.

However, while scrutinizing the syntactic, morphological and phonological environments where such vowels can occur we observe that in our Iźva Komi song these insertions cannot always be simply analysed as metrical epenthetic vowels. For instance, inserted [-e] can often also be analysed as a first person singular possessive suffix. Likewise, [-i] resembles a coordinating conjunction or discourse particle, with [i] being phonologically bound to the preceding phrase or clause. This is illustrated by the example 1 above, because the line-final [i] (written in parentheses here) does not occur in any of the published transcripts, although it is clearly part of the recorded speech.

An interesting case of such ambivalence in interpretation in the sung version is connected to dialectal Komi variation known as l-vocalization. This is a phonological alternation between [l] and [v] such that the underlying phoneme /l/ remains in word-medial position, but is deleted in word- or syllable-final position, accompanied by lengthening of the preceding vowel (Saharova and Sel'kov 1976 , p. 21). Relevant instances occur regularly in the text, as is to be expected for this subvariety of Iźva Komi. In actual fact word-final /l/ in the Iźva dialect is retained in some morphological forms, including the imperative when formed with the morpheme /-il/ (Saharova and Sel'kov 1976, p. 20). As one would expect, l-vocalization also features in Vászolyi's transcript, as for instance in vajle, voke, vośtyl, vośtyl! (Vászolyi-Vasse and Lázár 2010, 61, line 219). However, inspection of the original recording shows that in fact a short [e] vowel is perceivable in word-final position in the words in this line ending in $/ 1 /$, hence [-ill-e].

There are two possible readings to account for this additional segment. The first reading is similar to Vászolyi's interpretation (who did not transcribe the additional segment), namely that these [e] vowels are due to the same metric epenthesis as described above.

(4) вайлэ, воке, восьтыл(э), восьтыл(э)

vajl-e, vok-e, voctil(e), voctil(e)

bring.FREQ-IMP.2PL brother-1SG open.FREQ.IMP.2SG open.FREQ.IMP.2SG

'Come on, brother, open it up!' (13755_2az.221 24:34-24:39) 
However, an alternative reading could in principle also be possible, namely that the additional segment [e] is a grammatical formative. According to this interpretation we could analyse all these forms as plural imperatives.

(5) вайлэ, воке, восьтылэ, восьтылэ

vajl-e, vok-e, voctil-e, voctil-e

bring.FREQ-IMP.2PL brother-1SG open.FREQ-IMP.2PL open.FREQ-IMP.2PL

'Come on, brother, open it up!' (13755_2az.221 24:34-24:39)

At first glance, the reading with imperative plural seems at odds with the song context, but when we look at the narrated version of this text (Vászolyi-Vasse and Lázár 2010, p. 69), it is clear that in this specific event there are two addressees, the brother and his wife, who are told to open the door to their hiding place. Analysed as plural imperatives (i.e. our alternative reading which differs from Vászolyi's), imperative marking in the whole line would then symmetrically occur in the three verbs (but would not match the noun marked for singular).

Acoustic inspection reveals that all three plural-marking [e] vowels are less than 60 milliseconds long. This is considerably shorter than other word-final vowels, but the vowel formants are relatively clearly present. Therefore, we do not want to propose a conclusive result at this point. Our example, however, illustrates clearly the subjective status of any transcription choices in such data samples. As a result of the present study, the original audio recording is digitally available now and all interpretative transcriptions (e.g. Vászolyi's transcription, our alternative transcription and new, future interpretations) can be digitally aligned to the speech signal. This enables easier validation of former interpretations or - perhaps - completely new hypotheses. Therefore, digital publication of primary data linked to linguistic annotations (as well as other metadata, like described in the sections above) is best practice in documentary linguistics, as described in the next section.

\section{Documentary linguistic observations}

The sister fetched him everything...

(Ulita Koskova, in Komi; 13755_2az.059 12:41-12:45)

The recording and related metadata discussed here constitute only a small fraction of the 'documentary record'9 of Komi, i.e. the complete inventory of all legacy data collected and annotated by various actors during several centuries which generally aims at documenting Komi language and culture. Even materials collected without the implicit aim to 'document' can potentially be part

\footnotetext{
9 The term 'documentary record' refers to the totality of existing documents to study a given language (or culture, for that matter) beyond just individual corpora created by single researchers or projects.
} 
of the Komi documentary record, including theoretical studies on specific topics in, for instance, ethnology, ethnomusicology, history, and linguistics.

The documentary record of a spoken language is typically incomplete because only part of it is accessible, and some parts are indubitably lost. Materials may never have been archived or catalogued and may therefore be (exceedingly) hard or impossible to find. Other materials may have been destroyed, for various reasons in- or outside the responsibility of the involved actors. Parts of the 'record' can be defect - or have become defective at some time -, for instance due to the decay of analogue or digital data carriers (e.g. paper, magnetic tapes, or DVDs) or data loss during digitization (e.g. of tape recordings) or digital re-coding (e.g. pre-Unicode texts to Unicode).

Research practices in fieldwork-based linguistic documentation and description of languages and cultures - a field called 'documentary linguistics' by Himmelmann (1998), but ultimately going back to linguistic anthropology - have changed enormously during the last century. These changes are partly related to the digital turn in research methodology, but partly also due to evolving new research agendas. The research history in the ethno-linguistic area described in our paper nicely illustrates these changes, but also shows traits of temporal continuity.

Our own agenda with this present paper is consistent with documentary linguistics insofar as we strive for a "long lasting, comprehensive, multi-faceted and multi-purpose records of linguistic practices characteristic of a given speech community" (which is part of common definitions of the field by, e.g., Himmelmann 2002; Woodbury 2003; Austin 2014). However, we basically only have some minor comments about the recording under discussion, and we do not add completely new materials to the documentary record either. Rather, what we intended to do in this small study is tinker with the metadata for the purpose of better contextualisation of these limited legacy records, i.e. re-conceiving metadata in line with Nathan's and Austin's "language documentation through thick and thin" (Nathan and Austin 2004) and Austin's "meta-documentation" (Austin 2013).

In order to contextualize the present recordings in both time and space (i.e. during the 1960s in and around the Bol'shezemelskaja Tundra) one can start by comparing Vászolyi to his predecessors, foremost to the Finnish linguist Matthias Alexander Castrén (1813-1852). Castrén travelled in this area in 1843 (for more details, see Lukin 2017, p. 180). His collections form an extremely important part of the documentary records of both Nenets and Komi. As expected, there were no recording devices available in Castrén's time, and transcripts were recorded in writing while working with the informant. Accordingly, for instance, the aforementioned epenthetic vowels and syllables are not present in Castrén's materials, as it was not possible to transcribe them exactly from the sung version directly. As we have shown above, Vászolyi also scarcely paid any attention to this feature, similar to other early researchers after Castrén (for instance in Lehtisalo's Nenets materials, mentioned by Lukin 2015, p. 4).

There is, however an unmistakable difference here, since in Vászolyi's case not marking these vowels can be seen as an editorial decision, and they can 
always be analysed from the audio recordings, whereas for Castrén and Lehtisalo this choice creates a more fundamental difference in the documentation process because their textual annotations are the closest we can come today to the primary data they actually collected.

Lehtisalo's work is in fact an apposite illustration of how early the transition to the use of audio recording actually started. Niemi (2016, p. 20) describes how Lehtisalo carried a phonograph with him in 1911-12. However, he used this only as an additional tool, and the few recordings on wax cylinders are not connected to the transcriptions in his publications (Niemi 2016, p. 20). Still, one could argue from the documentary point of view that even this type of recordings are important as they at least offer auditory evidence for some of the sounds which the transcription tries to code.

Besides the change in technology, there is also a clear development of metadata practices. With Castrén's materials it is not known who the individual consultants are, whereas Lehtisalo already indicates this clearly, although there is no exact information about the session context (Lukin 2015, p. 4). In Vászolyi's materials each speaker, their birthplace and general background is described. The primary difference with regard to contemporary data would be that this information is provided in the form of published texts, which also then includes only the published parts, whereas nowadays the goal is to include this information in the archive, linked to the primary data. Actually this also already happens with Vászolyi's materials, as at least some identifiable metadata is stored with the recordings in the Institute for the Languages of Finland. The broader question is then how descriptive information from the publications, and potential additional information in other archives, should be connected more thoroughly to create a better interlinked dataset.

Our attempt at a reconstruction of Vászolyi's field research (incl. the chronological events, the actors involved, the relevant archived materials and publications, etc.), described in the sections above, already provides more complete meta-documentation than was available before. Listening to the original audio recordings, we found evidence for various additional details which, according to best practise in contemporary documentary linguistics, should become part of the metadata record. For instance, in the original audio there is background noise recorded which clearly indicates the opening of a door (13755_2az.188), which, in all likelihood, means that one actor either left the event or joined it. Vászolyi also describes in a footnote how Koskova tries to describe the story she narrates with a gesture, and he also mentions whispering or susurration that can be heard (Vászolyi-Vasse and Lázár 2010, p. 70), perhaps to an unknown actor present during the recording. Although Vászolyi's footnote does not replace visual information (that nowadays could easily be recorded on video), it still is worth emphasizing that detailed descriptions of the individuals who participated in the recorded session can also contribute meaningfully to a deeper analysis of the recorded event.

In addition to information about who is present during a recording or in what environment the data was collected, contemporary documentary linguistics and 
linguistic anthropology is also particularly sensitive to information concerning interaction between actors. In the prose version of the story there are even more examples of interaction, including with the audience, which obviously includes persons unknown to us. As mentioned above, part of this is non-verbal, and laughter can be heard. However, this gives us very important information about how the audience responded to the original performance. In another instance, an unknown male voice reacts to an event in the story, where the dead brothers are killed by piercing them with a type of pole. The narrator says "there they stand", and one person in the audience comments "they still stand".

Note that such interactions typically seem to be present in other documents on Komi as well (such as story-telling recorded by various researchers), although they are not always annotated in the transcriptions or mentioned elsewhere. For instance, a very similar communication act between a recorded narrator and the interviewer is located at the end of the story 'Blackgrouse Shooting' recorded in Udora just a few weeks before the text studied here was recorded (Vászolyi-Vasse 1999, p. 440). Exactly as in the case of the present study, we came across this interaction only while listening to the original audio.

Whereas paying attention to such marginal details may seem exaggerated, there are also situations where such interactions may be crucial for the correct understanding of the narrated events. For instance, there is an episode in our story where a character throws a piece of meat outside the conical tent known in Northern Russia as a 'chum'. According to the description, this happens through the smoke hole, which does not seem to be a typical use of this aperture. However, this detail may be present in the narrative for a comical effect. ${ }^{10}$ In the audio of the story's prose version we can indeed hear laughter in this phase (13756_2bz.159 31:05-31:07), which definitely strengthens such an analysis.

Last but not least, we find it important for documentary linguistics to strive for an ethnography of speech and communication beyond individual languages. If the function of the 'documentary record' is to document the linguistic practices of a given community within a more holistic perspective, but the community has undergone a language shift, the only sensible solution would be to treat all material, irrespective of the language, as part of the same documentary record.

\section{Language technology observations}

Where on earth art thou taking it?

(Ulita Koskova, in Komi; 13755_2az.100 15:41-15:45)

Language technology also has an important role to play in the enrichment of existing annotations. The availability of Finite State Morphology for Standard Zyrian Komi is mainly due to the substantial work carried out by Jack Rueter (Rueter 2000), who has been working on adapting the morphosyntactic analyser to dialectal Komi material; even when used in its current state of development it

${ }^{10}$ Thanks to Karina Lukin for pointing out such a possibility based on the published text version.

In Hämäläinen, M., Partanen, N., Alnajjar, K. (eds.) Multilingual Facilitation (2021), pages 208-227. -- CC BY 4.0 
has already shown its usefulness. There were individual rare loanwords that were not yet detected by the morphosyntactic analyser, but they would be easy to add to the lexicon files (Rueter, Kokkonen, and Marina Fedina 2020) as they are also present in the Komi dialect dictionary (Beznosikova, Ajbabina, Zaboeva, and Kosnyreva 2012). Ideally, the automated integration of dialectal vocabulary into the rule set of the Komi morphosyntactic analyser could be undertaken within the computational lexicographic infrastructure for Komi and other Uralic minority languages developed by Jack Rueter and others (Rueter and Hämäläinen 2017; Alnajjar, Hämäläinen, and Rueter 2020; Alnajjar, Hämäläinen, Rueter, and Partanen 2020).

On the other hand, the majority of morphological dialectal features are already covered by the existing rules in the analyser, and a comparison to the Spoken Komi Corpus (Blokland, Chuprov, Maria Fedina, Marina Fedina, Levchenko, Partanen, and Rießler 2021) reveals that essentially all dialectal morphological processes (including inflection as well as the - more rarely occurring - derivational deviations) are such that they do have parallels in other Komi materials. From this point of departure it is clear these forms will be eventually added to the rule set of the morphosyntactic analyser.

There are still very particular challenges for the application of the existing FST morphology to spoken language data in general and to this type of musical text in particular; in our case they are the epenthetic vowels and other spoken features. How challenging these features are depends on how exact we want the transcript to represent recorded speech.

For instance, we could move the epenthetic vowels to a different annotation layer and just use orthographic spelling for the transcript - similar to Vászolyi's transcription which leaves out the epenthetic vowels - and as input for the morphosyntactic analyser. Alternatively, if there is a consistent way to separate the epenthetic vowels from ordinary vowels in the transcription, they can be parsed and removed during an additional preprocessing step before being sent to the morphosyntactic analyser.

Similarly, false starts, hesitations and corrected speech segments smaller than an analysable word could be marked in the transcript in a consistent way and handled during preprocessing. Currently, we transcribe them impressionistically with a dash at the end but do not have any preprocessing rules in place yet.

Since we generally use orthographic transcription, but adapt it to non-standard forms, we also want to mark the epenthetic vowels with bracket for emphasis. As it seems they can appear in a wide variety of positions, see e.g. in this song the examples кӧр(е), чер(и)нас, нярт(а)ласэ and куль(ы)ны, it can be difficult to describe them using two-level morphology rules if they are written without being separately marked by any conventions. It may be possible to add such vowels individually for the most common words by examining a corpus of existing texts, but to be able to analyse these in new texts is a challenge.

Besides false starts, self-corrections and hesitations, there are other challenges for syntactic analysis. At the moment the text is chunked according to the (poetic) lines of the original print publication(s) of the song, rather than utterances 
or using speech pauses as clues for chunking. In some versions of the printed texts punctuation is used, following the conventions of written language for marking sentences, clauses or phrase coordination. Sentences marked by means of punctuation are, however, relatively long, and it is unclear whether the punctuation at verse boundaries describes the most meaningful units in texts of this type. If the line and verse level phenomena are of importance, these elements could also be marked with some other conventions than the punctuation currently used.

Although the authors' own evolving solutions for integrating natural language processing into documentary linguistics (Blokland, Gerstenberger, Marina Fedina, Partanen, Rießler, and Wilbur 2015, described in several papers since) are still only preliminary, it is clear that developing tools and best practice for efficient and systematic corpus annotation is a real-world task where solutions will be beneficial for computational and documentary linguistics beyond the Komi context.

\section{Discussion}

Thank God, it ends now.

(Erik Vászolyi, in Hungarian; 13755_2az.241 07:42-07:49) ${ }^{11}$

The 'Ballad of the soft-haired sister' and similar materials are an integral part of the documentary record that is available for the under-resourced Komi language, and represent a text type that can no longer be recorded because there are no longer any native speaker performers of this particular song type. In this small contribution to the Festschrift we wanted to show that taking a new look at these already published and analysed materials can lead to a number of valuable observations. In general, the construction of current corpora should always take all earlier work seriously into account and actively try to integrate it.

We have not only discussed this as a methodological issue, but carefully looked at the history of this small text sample, reconstructed various missing details in the metadata, and additionally contextualized the relevant original fieldwork events as well as later work with this document. While doing so we have shown, that by carefully going through related publications and descriptions of the work, we can reconstruct the events relatively accurately, and bring legacy recordings, transcripts and metadata annotations into a state where they are comparable with contemporary spoken corpora. As a result, we are able to link the original primary data to various levels of annotations and interpretations (including our own) and make it available digitally with richer metadata and commentary (Blokland, Partanen, and Rießler 2021).

We can also show that the current NLP environment for Komi (based on FST morphology) has reached a level where such materials can be fairly effortlessly analysed and studied, though at the same time there are challenges for the processing pipeline due to the specific speech genre (i.e. music) represented by our

$\overline{11}$ This quote - originally in Hungarian - is not from the English translation of the published texts, but a comment by Vászolyi found in the audio recording. 
data. Other spoken language features, such as false starts and self-corrections, should also be taken into account more systematically, both in the transcript and the Komi NLP model. Furthermore, we have discussed how computational modeling of phonology, morphosyntax and lexicon could be developed such that work on (written and spoken) standard and dialectal Zyrian Komi can be unified in the future.

Last but not least, our work has shown the potential that legacy data still has today. The unique Nenets-Komi character of our speech sample, part of the Kolva epic tradition, is unmistakable. However, an understanding of exact models of contact influence between Nenets and Komi is still in need of more thorough sociolinguistic, ethnomusicological and anthropological investigations, which ideally would occur as collaboration between researchers representing these different fields. The way we publish and annotate this individual text also creates one possible example of how these materials could be created and studied collaboratively across the above-mentioned fields, as was already pointed out by Vászolyi himself:

Granny Ulita's heroic sagas and ballads deserve our attention in more ways than just one inasmuch as they are relevant to the Samoyedologist just as much as to the Finno-Ugrist focusing on Komi, to the linguist as well as to the folklorist or anthropologist.

(Vászolyi-Vasse and Lázár 2010, p. 24)

\section{References}

Alnajjar, Khalid, Mika Hämäläinen, and Jack Rueter (2020). "On editing dictionaries for Uralic languages in an online environment". In: Proceedings of the Sixth International Workshop on Computational Linguistics of Uralic Languages. Vienna: Association for Computational Linguistics, pp. 26-30.

Alnajjar, Khalid, Mika Hämäläinen, Jack Rueter, and Niko Partanen (2020). Ve'rdd. Narrowing the gap between paper dictionaries, low-resource NLP and community involvement. Preprint, arXiv:2012.02578.

Austin, Peter K. (2013). "Language documentation and meta-documentation". In: Keeping languages alive. Documentation, pedagogy and revitalisation. Ed. by Mari Jones and Sarah Ogilvie. Cambridge: Cambridge University Press, pp. 3-15.

- (2014). "Language documentation in the 21st century". In: JournaLIPP 3, pp. $57-71$.

Baker, Robin (1985). The development of the Komi case system. A dialectological investigation. Helsinki: Suomalais-Ugrilainen Seura.

Beznosikova, Ljucia M., Evgenija A. Ajbabina, Nadezhda K. Zaboeva, and Raisa I. Kosnyreva (2012). Slovar' dialektov komi jazyka. V dvuh tomah. Bolee 78000 slov. Syktyvkar: Kola. 
Blokland, Rogier, Vasily Chuprov, Maria Fedina, Marina Fedina, Dmitry Levchenko, Niko Partanen, and Michael Rießler (2021). Spoken Komi Corpus. The Language Bank of Finland, forthcoming version 0.1. URL: http://urn. fi/urn:nbn:fi:lb-2019121603.

Blokland, Rogier, Ciprian Gerstenberger, Marina Fedina, Niko Partanen, Michael Rießler, and Joshua Wilbur (2015). "Language documentation meets language technology". In: Proceedings of the First Workshop on Computational Linguistics for Uralic Languages. Tromsø: Association for Computational Linguistics, pp. 8-18.

Blokland, Rogier, Niko Partanen, and Michael Rießler (Mar. 8, 2021). Spoken Komi Corpus: Erik Vászolyi. Zenodo data repository. DOI: 10.5281/zenodo. 4591281.

Habeck, Joachim Otto (2005). What it means to be a herdsman. The practice and image of reindeer husbandry among the Komi of northern Russia. Vol. 5. Münster: LIT Verlag.

Himmelmann, Nikolaus P. (1998). "Documentary and descriptive linguistics". In: Linguistics 36, pp. 161-195.

- (2002). "Documentary and descriptive linguistics (full version)". In: Lectures on Endangered Languages 5. Ed. by Osamu Sakiyama and Fubito Endo. Kyoto, pp. 37-83.

Homič, Ljudmila V. (1966). Nency. Istoriko-ètnografičeskie očerki. Moskva: Nauka.

Istomin, Kirill (1999). "Kolva Volost and Kolva ethnographic group as an example of transition from nomadic to settled way of life. An attempt of analysis". In: Pro Ethnologia 8, pp. 19-34.

Kaheinen, Kaisla (2020). "Nganasanin itsekorjaus. Huomioita korjaustoimintojen rakenteesta ja korjauksen merkityksista vuorovaikutuksessa". MA thesis. University of Helsinki.

Klumpp, Gerson (2008). "Differentielle Objektmarkierung \& Informationsstruktur in Dialekten des Komi". Habilitation. München: Fakultät für Sprach- und Literaturwissenschaften der Ludwig-Maximilians-Universität München.

- (2009). "Variation in Komi object marking". In: Describing and modeling variation in grammar. Ed. by Andreas Dufter, Jürg Fleischer, and Guido Seiler. Berlin: De Gruyter Mouton, pp. 325-359.

Lašuk, Lev P. (1958). Očerk ètničeskoj istorii Pečorskogo kraja. Opyt istorikoètnografičeskogo issledovanija. Syktyvkar: Komi Knižnoe Izdatel'stvo.

Lázár, Katalin (2007). "Komi játékdalok Vászolyi Erik gyüjtéséből (1960, 1966)". In: Zenetudományi dolgozatok 2006-200\%. Budapest: MTA Zenetudományi Intézet, pp. 215-235.

Lehtisalo, Toivo (1956). Juraksamojedisches Wörterbuch. Helsinki: SuomalaisUgrilainen Seura.

Lukin, Karina (2015). "Matka ja liike nenetsien epiikassa ja šamanistisessa runoudessa". In: Elore 22.1, pp. 1-31.

- (2017). "Matthias Alexander Castrén's notes on Nenets folklore". In: Journal de la Société Finno-Ougrienne 96, pp. 169-211. 
Lytkin, Vasilij I. (1949). "Fonetika severnovelikorusskih govorov i zaimstvovanija iz russkogo jazyka v komijskij". In: Materialy i issledovanija po russkoj dialektologii. Vol. 2. Moskva: Akademija nauk SSSR, pp. 180-185.

Mikušev, Anatolij K. (1969a). Komi épičeskie pesni i ballady. Moskva: Nauka.

- (1969b). "Kolvasa èpos". In: Vojvyv kodzuv 11, pp. 49-52.

- (1973). Épičeskie formy komi fol'klora. Leningrad: Nauka.

- (1991). Komi épicheskaya poėziya. Leningrad: Sovetskij pisatel'.

Nathan, David and Peter K. Austin (2004). "Reconceiving metadata. Language documentation through thick and thin". In: Language Documentation and Description. Vol. 2, pp. 179-187.

Niemi, Jarkko (2016). "Description of poetic form as a tool for stylistic analysis of a traditional song performance. A case of a western Nenets narrative song". In: RMN Newsletter 9, pp. 17-32.

Panjukov, Anatolij V. (2015). "Ižmo-kolvinskij èpos. Vstreča tradicii". In: Izvestija Komi naučnogo centra UrO RAN 4.24, pp. 108-119.

Povod, Nina A. (2006). Komi severnogo zaural'ja (XIX-pervaja četvert' XX v.) Novosibirsk: Nauka.

Punegova, Galina V. and Rimma P. Popova (2019). "Funkcionirovanie affrikat v komi jazyke". In: Linguistica Uralica 55.1, pp. 36-46.

Rakin, Nikolaj A. (2017). "Komi (zyrjanskaja i permjackaja) literatura na vengerskom jazyke". In: Vestnik ugrovedenija 29.2, pp. 76-84.

Rueter, Jack (2000). "Hel'sinkisa universitetyn kyv tujalys' Ižkaryn perymsa simpozium vylyn lydd'ömtor". In: Permistika 6 (Proceedings of Permistika 6 conference), pp. 154-158.

Rueter, Jack and Mika Hämäläinen (2017). "Synchronized Mediawiki based analyzer dictionary development". In: Proceedings of the Third Workshop on Computational Linguistics for Uralic Languages. St. Petersburg: Association for Computational Linguistics, pp. 1-7.

Rueter, Jack, Paula Kokkonen, and Marina Fedina (Dec. 7, 2020). Komi-Zyrianto-X dictionary work. Zenodo data repository, version 0.5.1. DOI: 10.5281/ zenodo. 4309763.

Saharova, Marfa A. and Nikolaj N. Sel'kov (1976). Ižemskij dialekt komi jazyka. Syktyvkar: Komi Knižnoe Izdatel'stvo.

Vasoj, Ėrik and Katalin Lazar (2010). «Vyrosla v boru strojnaja sosna...» (Pesni Zemli Komi). Trans. by Nikolaj A. Rakin. Syktyvkar: Kola.

Vaszolyi, Erik and Katalin Lázár (2008). "Sudar fenyő nőtt az erdön". Énekek Komiföldröl. Tinta Könyvk.

Vászolyi, Erik (1967a). "Északi zürjén epikus énekek". In: Ethnographia 78, pp. $438-451$.

- (1967b). "Második zürjénföldi tanulmányutam". In: Nyelvtudományi Közlemények 69, pp. 435-439.

- (1968). "Északi zürjén epikus énekek (Második közlemény)". In: Ethnographia 79.1 , pp. $76-91$.

Vászolyi-Vasse, Erik (1999). Syrjaenica. Narratives, folklore and folk poetry from eight dialects of Komi. Upper Izhma, Lower Ob, Kanin Peninsula, Upper 
Jusva, Middle Inva, Udora. 15. Szombathely: Seminar für Uralische Philologie der Berzsenyi Hochschule.

Vászolyi-Vasse, Erik (2001). Syrjaenica. Narratives, folklore and folk poetry from eight dialects of Komi. Kolva and Usa. Ed. by János Pusztay. 17. Szombathely: Seminar für Uralische Philologie der Berzsenyi Hochschule.

Vászolyi-Vasse, Erik and Katalin Lázár (2010). Songs from Komiland. Solymár: Reguly Társaság.

Woodbury, Anthony C. (2003). "Defining documentary linguistics". In: Language documentation and description 1, pp. 35-51.

Žerebcov, Ljubomir N. (1982). Istoriko-kul'turnye vzaimootnošenija komi s sosednimi narodami. Moskva: Nauka. 